\title{
Lingo-Cognitive Aspects as a Formation of an Image of a Native Russian Speaker for a Foreigner While Studying In Russia
}

\author{
Golovaneva Marina Anatolievna ${ }^{1 *}$ \\ Associate Professor, Astrakhan State University, \\ Astrakhan, Russia. \\ Saparova Ogulbossan Agamyradovna ${ }^{2}$ \\ Student, Astrakhan State University, \\ Astrakhan, Russia. \\ Saparov Atamyrat Agamyradovich ${ }^{3}$ \\ Student, Astrakhan State University, \\ Astrakhan, Russia.
}

(date of receiving: June, 2021; date of acceptance: July, 2021)

\begin{abstract}
The purpose of this study was to identify the means of objectification of the cognitive structure "Russians", which is formed in the linguistic consciousness of foreigners, and to suggest ways of linguo-didactic correction of the process of its formation. The article examines the cognitive mechanisms of transformation of key cognitive structures, in particular, the concept "Russians" in the minds of foreigners studying in Russia. The conclusion about the mental transformative role of the language is made. The results of the research were the following methods of work proposed for use: "cross-use" of regional study materials in different disciplinary courses; compulsory and regular reference in the process of mastering Russian grammar to text and speech material of a regional nature; compulsory involvement in independent work on the preparation of monologues, dialogues and polylogs of country-specific material. The theoretical significance of the work lies in strengthening the position of the linguistic and cultural and linguo-cultural component of the methodology of teaching Russian as a foreign language. The practical significance of the work follows from the obvious possibilities for the effective implementation of the proposed methods of educational activity at different stages of mastering the Russian language by foreign students in Russian higher education.
\end{abstract}

Keywords: Cognitive Structure, Consciousness, Mentality, Foreigner, Linguo-Didactic Techniques, Regional Material, Associative Experiment.

1. E-mail: yarrow@inbox.ru *Corresponding author

2. E-mail: bossansaparova@mail.ru

3. E-mail: atamyratsaparov@mail.ru 


\title{
О лингвокогнитивных аспектах формирования образа носителя русского языка у инофона при обучении в России
}

\author{
Голованева Марина Анатольевна ${ }^{\text {** }}$
}

Доцент, Астраханский государственный университет, Астрахань, Россия.

Сапарова Огулбоссан Агамырадовна ${ }^{2}$

Студентка, Астраханский государственный университет, Астрахань, Россия.

Сапаров Атамырат Агамырадович ${ }^{3}$

Студент, Астраханский государственный университет, Астрахань, Россия.

(дата получения: июнь 2021 г.; дата принятия: июль 2021 г.)

\begin{abstract}
Аннотация
Целью данного исследования стало выявление средств объективации когнитивной структуры «Русские», образующейся в языковом сознании инофонов, и предложение путей лингводидактического корректирования процесса её формирования. В статье рассматриваются когнитивные механизмы трансформации ключевых когнитивных структур, в частности, концепта «Русские» в сознании инофонов, обучающихся в России. Делается вывод о ментально-преобразовательной роли языка. Результатами исследования стали предложенные к применению следующие приёмы работы: «перекрёстное» использование страноведческих материалов в разных дисциплинарных курсах; обязательное и регулярное обращение в процессе усвоения русской грамматики к текстовому и речевому материалу страноведческого характера; обязательное привлечение к самостоятельной работе по подготовке монологов, диалогов и полилогов страноведческого материала. Теоретическая значимость работы заключается в усилении позиций лингвострановедческой и лингвокультурологической составляющей методики обучения русскому языку как иностранному. Практическая значимость работы следует из очевидных возможностей эффективной реализации предлагаемых приёмов учебной деятельности на разных этапах освоения русского языка иностранными обучающимися в российской высшей школе.
\end{abstract}

Ключевые слова: Когнитивная Структура, Сознание, Ментальность, Инофон, Лингводидактические Приёмы, Страноведческий Материал, Ассоциативный Эксперимент.

1. E-mail: yarrow@inbox.ru * Ответственный автор

2. E-mail: bossansaparova@mail.ru

3. E-mail: atamyratsaparov@mail.ru 


\section{Введение}

Вторичная языковая личность, находясь на территории изучаемого феномена, в соответствующей языковой среде, с неизбежностью обращена к когнитивной структуре, определяющей ключевые ментальные маркеры носителей данного языка. Стремление постичь чужой язык всегда сопряжено со стремлением постичь чужую ментальность, а также суть тех понятий, которые определяют национальную идентичность носителей изучаемого языка. Так, для туркменских студентов, приезжающих в Россию на обучение, в определённый период при формировании образа носителя изучаемого языка ключевым представляется концепт «Русские». Постижение его наполнения с неизбежностью производится сознаниями носителей туркменского языка, имеющего иные, чем русский, характеристики: алтайская семья, тюркская группа, огузская подгруппа (агглютинативный тип). Лингвокультурный мир туркменского инофона - студента требует расширения границ ключевой когнитивной структуры «Русские», уже имеющейся в его сознании, но обладающей лингвокогнитивной спецификой. Это обусловлено особенностями международных контактов, испытывающих влияние некоторой государственной закрытости и сдержанности туркменской стороны.

Коррективы концепта «Русские» в сознании туркменских инофонов считаем необходимыми в связи с большим влиянием его на лингвострановедческую и лингвокультурную области, формируемые у студентов при обучении русскому языку.

\section{Основная часть}

В отечественной и зарубежной лингводидактике нет значительных расхожденийввопросахнеобходимостиобращенияклингвокультурологическим и лингвострановедческим аспектам при обучении иностранному языку. 
Повышенное внимание к языку как части культуры, характерное, прежде всего, для социокультурной (межкультурной) методики, в настоящее время свойственно всем направлениям.

Так, российские учёные, ставшие основоположниками лингвострановедческой теории - Е. М. Верещагин и В.Г. Костомаров (Верещагин 1980; Верещагин 1990) - всегда ставили во главу угла проникновение в ментальную сферу носителей изучаемого языка. Авторы утверждали, что без постижения способа видеть мир, присущего народуносителю изучаемого языка, невозможно глубокое проникновение в его духовный мир, а следовательно, адекватное понимание механизмов данного языка. Е. С. Абезгауз (2011), А. А. Акишина (2017), Н. Ф. Алефиренко (2010), Ж. Багана (2010), Ю. В. Баканова (2006), Е. И. Воробьёва (1999), Н. Д. Гальскова (2004. 22-27), Т. Г. Грушевицкая (2003), В. И. Карасик (2002), Е. С. Красножёнова (2001. 54-59), А. А. Миролюбов (2002), Н. Н. Михайлов (2018), А. К. Перевозникова (2018), Ю. Е. Прохоров $(1995,2011)$, В. Н. Телия (1999. 14-15), С. Г. Тер-Минасова (2000. 15; 2007), Е. Ф. Тарасов (1998. 30-42; 1996. 47-49), Г. Д. Томахин (1996. 47-49), В. П. Фелицкая (1990), А. Н. Щукин (2003) высказывались в методических работах о разных аспектах формирования лингвокультурного знания у инофонов, при этом необходимость такого знания не ставилась под сомнение.

В работах зарубежных авторов Carter (2000), Scrivener (2005), Willis (2003), Oschepkova (2005), Ciggins P. (2002) прямо или косвенно указывается на эффективность антропоцентрической и лингвокультурологической окраски привлекаемых к обучению материалов. Зарубежные работы практического плана и наблюдения теоретического характера сходны в позициях опоры на национальноспецифический языковой и речевой материал, используемый в процессе обучения.

Таким образом, в указанных работах разного характера отмечается общая мысль о необходимости формирования у обучающихся способности 
«адекватно реагировать на проявление чужого, непривычного в поведении представителей иных культурных традиций. Способность к общению на межкультурном уровне предполагает у человека таких личностных качеств, как открытость, терпимость, готовность к общению» (Грушевицкая 2003. 22). Данная наиболее сильная позиция в российской лингводидактике, отражённая в отмеченных работах, разделяется и в нашем исследовании.

Материалами работы стали продукты речемышления студентов-инофонов. Объект исследования - процессы речемышления участников коммуникации среди туркменских студентов 1-5 курсов, обучающихся на различных факультетах Астраханского государственного университета, и дискурсивного освоения ими продуктов речемышления. Предметом исследования в данной работе стала когнитивная структура «Русские», образующаяся в языковом сознании инофонов, и пути дингводидактического корректирования процесса её формирования.

Антропоцентрическая методология предопределила выбор методов исследования, таких как лингвистический метод наблюдения, приём количественных подсчётов, ассоциативный эксперимент, приём дидактического анализа, приём когнитивно-дискурсивного анализа, приём обобщения.

Русский лингвокультурный мир окружает сознание инофона, прибывающего в Россию для обучения, и с неизбежностью корректирует ментальные установки иностранного студента. Этот процесс не является самоцелью процесса образования, но сопутствует ему как явление инкультурации. Ключевая когнитивная структура, терпящая значительные изменения, - концепт «Русские», входящий в сферу основных составляющих элементов образа носителя русского языка.

Нами был реализован эксперимент, выявляющий средства вербализации концепта «Русские» у туркменских абитуриентов Астраханского 
государственного университета, у туркменских студентов 1-5 курсов и у туркменских выпускников. Респонденты приводили актуальную лексику, соотносимую в их сознании с сочетанием-стимулом «русские люди». При этом организаторами эксперимента не актуализировались возрастные, социальные, профессиональные, гендерные характеристики прототипа, дающего когнитивный материал для инофона.

Г.Г. Слышкин рассматривает концепт как «многомерную ментальную единицу, детерминированную культурными фактами и обладающую способностью быть опредмеченной в разноообразной языковой форме» (Слышкин 2004. 105). Однако ближайшая перспектива данной работы определить максимальный спектр аксиологических суждений, выраженных в определениях.

Понятийная составляющая концепта «Русские» сообщает следующую информацию: «Восточнославянский народ, составляющий основное население РСФСР, живущий также в других республиках СССР (Ожегов 1989. 687); «Русские - 1. Восточно-славянский народ, составляющий основное население России. 2. Представители этого народа» (Ефремова 2015. 727); «Народ, основное население Российской Федерации» (БЭС 2006. 927).

В ходе пролонгированного многолетнего эксперимента абитуриенты и студенты отметили релевантность следующих слов-вербализаторов к словустимулу русский, которые были выбраны ими из предлагаемых списков прилагательных (приводится часть примеров): А: авторитарный, агрессивный, адекватный, азартный, аккуратный, активный, амбициозный, артистичный; Б: баламутный, бдительный, безбоязненный, безвкусный, безвредный, безжалостный, беззаботный, безотказный, безудержный; $\mathbf{B}$ : вдумчивый, вежливый, великодушный, верный, весёлый, взрывной, взыскательный, видный, внимательный, властный; Г: гармоничный, героический, гибкий, глубокомысленный, гневливый, гостеприимный, гордый, грамотный, 
грешный, грубый, грустный, гуманный; Д: дальновидный, двуличный, деловой, деликатный, дельный, демократичный, дерзкий, деятельный, дипломатичный, дисциплинированный, добродетельный, добродушный, доброжелательный $<\ldots>$.

Как явствует из отобранных инофонами определений, их аксиологический спектр весьма широк. Определения свидетельствуют как об одобрительной аттестации русского человека, так и о противоположной, негативной, например: общительный - малообщительный; открытый - закрытый, скрытный; активный - пассивный; лёгкий - тяжёлый; справедливый несправедливый; улыбчивый - мрачный; спокойный - издёрганный; доброжелательный - капризный; уравновешенный - гневливый и др.

Лингводидактические приёмы формирования нового знания, реализующиеся нами на занятиях русского языка как иностранного с туркменскими студентами, не являются абсолютно новыми, но тенденция их подбора и сочетания, наполнения языковым и речевым материалом обеспечивает эффект быстрого формирования нового культурологического, страноведческого знания. Концептуальные признаки единицы «Русские» при этом терпят изменения: исчезают, возникают, получают больший или меньший аксиологический вес.

В активе методических приёмов находятся следующие виды работ: 1) чтение и анализ текстов культурологической направленности (о российской государственности и государственной атрибутике, о праздниках государственных, народных и религиозных, о семье, приметах, ведущих профессиях, о российском образовании, об устном народном творчестве, о народных промыслах, о русской литературе и др.); 2) интерпретация русских пословиц и поговорок; 3) чтение наизусть стихов из русской классики; 4) толкование юмористических текстов (анекдотов, крылатых фраз, детских высказываний, потешных вопросов); 5) фонетическая зарядка только на 
материале русских скороговорок, чистоговорок и фрагментов русских стихотворений; 6) составление и озвучивание диалогов по проблемным вопросам (например, Зачем туркменам русский язык?; Чему ты удивился больше всего, когда приехал в Астрахань?; Я ещё не понимаю, почему русские...; Русский фильм, который меня поразил; и др.); 7) составление и озвучивание монологов на общую тему «Русские чудеса» (например, рассказ о цветке лотосе, который растёт только в низовьях Волги; о деревянном поселении Кижи; о монументе «Мать-Родина» в Волгограде и др.); иллюстрация терминов из раздела «лексика специальности» примерами только из русской классики (например, языковое средство аллитерращия сопровождается фрагментом из поэмы А. С. Пушкина «Полтава»: Швед, русский, колет, рубит, режет, бой барабанный, крики, скрежет...).

В результате анализа всех возможных текстовых, предложенческих, словосочетательных языковых примеров, а также в результате работы над диалогическими и монологическими структурами, инофоны, помимо освоения русского языка как системы, осваивают язык и как отражение российской действительности, как средство получения новых форматов знания о русском (российском) менталитете. Социокультурная картина мира инофона-туркмена начинает вбирать в себя новые фрагменты, касающиеся инородной российской жизни. Некие когнитивные образования, объясняющие отличие российской поведенческой, деятельностной, психологической реакции на мир, возникают в основном при реализации приёмов развития речи инофонов, реже - в процессе грамматического тренинга. Именно макро- и микротексты позволяют инофону проникнуть в ментальную сферу другого этноса: «Язык - мощное общественное орудие, формирующее людской поток в этнос, образующий нацию через хранение и передачу культурных традиций, общественного самосознания данного речевого коллектива» (Тер-Минасова 2000. 15). Инофон воспринимает готовые блоки этнически иной информации, созданные 
средствами русского языка, а также сам русский язык как иностранный в аспекте его системности. Языковое сознание инофона расширяется, включая в себя факт существования иной, русской языковой системы и связанного с ней, а также смоделированного ею иного ментального мира. Овладение иностранным языком «удваивает» мир, прибавляя новую культурную территорию, открывая возможности иного понимания той же окружающей объективной реальности. «Наша собственная культура задаёт нам когнитивную матрицу для понимания мира, так называемую картину мира» (Попова 2002. 67-68), приобщение к иной культуре позволяет внести коррективы в первую очередь в те когнитивные структуры инофона, которые позволяют ему осмыслить чужую социокультурную «территорию». Среди них в нашей когнитивной ситуации - концепт «Русские». Бесспорно, в данном случае при рассмотрении проблемы концепта приходится ориентироваться как на когнитивный, так и на лингвокультурологический подход. Первый объясняет когнитивные механизмы преобразования сознания инофона, второй - аспекты зависимости этого преобразования от лингвокультурной и этнической специфики обеих сторон описываемого процесса.

В ходе осмысления компонентов концепта «Русские» (понятийного, образного, нормативно-оченочного (Карасик 2002. 174), ассочииативного, этнокультурного) инофоны выявляют спектр новых качеств гражданина России, что позволяет им глубже проникнуть в мир изучаемого языка.

Так, понятие русские даже при том условии, что студенты-первокурсники до прибытия в Россию знали об отличии национального признака «русский» от социального статуса «гражданин России», посредством перечисленных выше упражнений дополняется знанием о многонациональном составе населения страны, об особенностях расселения этносов, о фактах компактного и смешанного проживания национальных групп, о специфике смешанных браков, о государственной национальной политике. 
Крайне редки случаи, когда студент-иностранец владеет всеми аспектами данного понятия и нуждается только в личных контактах с представителями разных этносов России, проживающих в Астрахани, для формирования образного и нормативно-оценочного компонентов концепта. Чаще понятийная составляющая требует дополнения посредством проведения следующих работ: 1) использования в курсе различных языковых дисциплин текстов страноведческого характера; 2) обращения в процессе усвоения русской грамматики к текстовому и речевому материалу страноведческого характера; 3) привлечения к самостоятельной работе по подготовке монологов, диалогов и полилогов страноведческого материала и др. Так, в первом случае применяется «перекрёстная» схема работы с материалами учебника лингвострановедения, созданного кафедрой русского языка как иностранного Астраханского государственного университета (Бадалова 2020) для студентов педагогических специальностей с двумя профилями подготовки, в том числе, и по специальности «Русский язык как иностранный». Данная схема заключается в использовании анализа статей или их фрагментов не только на лингвострановедческих занятиях, но и в формате «Практического курса русского языка», «Практики русской речи», «Методики обучения русскому языку как иностранному». Речь идёт не о дублировании работы, а о различных её аспектах.

Приведём выдержку из актуальной статьи: «... Но миграционная ситуация в Астраханской области не вызывает тревоги. В других регионах приток мигрантов очень высокий, что иногда вызывает национальное напряжение. А Астраханский край издавна был многонациональным. В нём, как в капле воды, всегда отражался национальный состав России. Например, сейчас в Астрахани и области проживают представители почти 173 этносов! При этом национальной розни нет. Как и всегда, в нашем регионе царит национальное взаимопонимание. Все жители прекрасно осознают важность мира и дружбы и берегут добрососедские отношения. Веротерпимость у нас складывалась 
веками, и чтобы не потерять её, в области создано 19 национально-культурных обществ. Эти организации стали мостиком между этническими группами и властью. Они издают газеты, ведут вещание на четырёх языках: русском, казахском, ногайском, татарском. В местах компактного проживания групп есть национальные школы. Каждая этническая группа уверена, что проживает на своей исторической родине.

Национальный состав, как уже отмечалось, в нашем крае очень разнообразен. Всегда наибольшее количество жителей составляли русские - 76 \%. Вторая по количеству человек диаспора - казахи - 12\%. Третья - татары 8\%. Кроме этих народов, в крае постоянно проживают украинцы, азербайджанцы, ногайцы, чеченцы, калмыки, армяне, цыгане, аварцы, лезгины, даргинцы, корейцы, узбеки, туркмены, белорусы, кумыки, турки, табасараны, грузины, таджики, немцы, чуваши, мордва, евреи, лакцы, башкиры, молдаване и люди других национальностей.

Задание 1. Расскажите о народонаселении Вашего родного города, района в той стране, где Вы родились и выросли. Сравните количество жителей в Вашем населённом пункте и в Астраханской области. Сделайте вывод о принадлежности этих территорий к большим, средним или небольшим государственным территориальным объектам. Порассуждайте о том, влияет ли величина территории, количество населения на уровень экономического и культурного развития региона.

Задание 2. Напишите правильно все названия национальностей, выявляемых в Астраханской области, в именительном падеже, в единственном числе, например: азербайджанец.

Задание 3. Приведите лексическое значение следующих слов и выражений: перепись населения, плотность населения, мигранты, национальное напряжение, веротерпимость, этническая группа, историческая родина, нацуиональный состав». 
Приведённый фрагмент может использоваться по прямому назначению на лингвострановедческом занятии, но и как материал для формирования понятия «русские», аксиологического наполнения когнитивной структуры «Русские» в курсе иных дисциплин.

При этом роль учебных макро- и минитекстов остаётся большой: образный компонент составляется из многообразия образов, воссозданных в учебных художественных, публицистических, фольклорных и научных текстах. Например, текст о промысла России даёт представление не только о традиционных занятиях россиян, ставших в некоторой степени национальным искусством, но и о чертах национальной души, склонной к производству красоты: «В последние четыре века в различные периоды в России возникали народн... промыслы. Промысел - это ремесло, которым занимались цел... семьи и даже целые сёла. В некотор... случаях ремесло становилось искусством. И тогда название села делалось названием эт... промысла. Таких сёл, известных не только в России, но и во всём мире, немного <...>».

Нормативно-оценочный компонент формируется посредством эксплицитной или имплицитной оценки всех описанных в текстах предметов, явлений и событий с позиций собственного менталитета. Для ускорения его формирования и для прочности приобретаемых элементов на занятиях регулярно практикуется продуктивная речевая деятельность студентов, в которой обязательной составляющей является оценочная часть. Побуждение к оценке, к её соотнесению с собственными национальными ценностными ориентирами должно стимулировать не только расширение лексического запаса, привитие навыков оформления жанрово соответствующего высказывания, но и строительство новых когнитивных структур, участвующих в образовании положительных черт образа носителя русского языка. Приобретаемая информация, расширяющаяся картина мира, регулярная установка на нормативно-оценочный компонент учебного общения, 
бесспорно, служат развитию когнитивной сферы студентов-инофонов. Не всегда первое восприятие ими российских реалий бывает положительным и однозначным, тем не менее, проводимая на занятии работа по семантизации ключевых аксиологических понятий, определений, приложимых к базовому сочетанию «русский человек», «русские люди», даёт ощутимый результат, хотя иногда отсроченный во времени. Так, периодически проводимый эксперимент с теми же предлагаемыми прилагательными свидетельствует о постепенном уменьшении негативных характеристик. Например, одна из групп респондентов отметила меньше отрицательных оценок в конце 5-го года обучения, чем в конце 1-го (нами приведены прилагательные, начинающиеся с букв А, Б, В. Количество респондируемых студентов - 67 (Таблица 1).

Следовательно, процессы инкультурации, расширения картины мира, приобретения нового знания о русских носителях русского языка, целенаправленная лингводидактическая работа на занятиях по русскому языку дают ощутимый результат: частотность избираемой негативной характеристики с течением времени уменьшается, что говорит о формировании всё более положительного образа русского носителя русского языка в сознании туркменских инофонов. 
Таблица 1. Выбираемые инофонами слова-вербализаторы к слову-стимулу «русский»

\begin{tabular}{|c|c|c|c|c|c|}
\hline & & & \\
\hline
\end{tabular}

Ассоциативный компонент возникает путём связывания русского феномена со всеми возможными социокультурными явлениями жизни. Намеренное привлечение к работе на занятии и в самостоятельном сегменте таких материалов, которые раскрывают максимум сфер жизни русского человека, позволяет раскрыть многогранность образа русского носителя русского языка. Отмеченные приёмы работы способствуют данному направлению, расширяя границы картины русской жизни в сознании инофона. 
Этнокультурный компонент формируется путём сопоставления, с одной стороны, русской национальной культуры, с другой стороны, национальной культуры инофона, и с третьей стороны, всех других известных ему культур. Так, весьма часто на занятиях с этой целью рассматриваются материалы, позволяющие сравнить русский менталитет с иными, не только с туркменским. Расширившиеся в последние годы для туркмен возможности осмысления заграничного мироустройства позволяют проводить указанные сравнения без опасности задеть национальные чувства туркменских инофонов и подвергнуть их осуждению соотечественников. Подобные процедуры позволяют осторожно повернуть учебное общение в русло жизненных рассуждений, выдвинуть на первый план положительные стороны русского менталитета, найти точки схожести его с туркменским менталитетом и, тем самым, укрепить положительный образ русского носителя русского языка.

\section{Заключение}

Таким образом, на каждом этапе обучения инофона его концептуальная сфера оказывается в определённой степени изменённой ввиду осуществления работы когнитивных механизмов. Практическая ценность «трансформации» в сознании иностранного студента концептов, например, концепта «Русские» заключается не только в приобретении концептом неких положительных признаков, но и в том, что инофон получает возможность наблюдения за ментально-преобразовательной деятельностью языка, за проявлением его жизненной силы, реальным влиянием на мысль и чувство человека.

В работе нами были сделаны выводы о неуклонном изменении в течение 45 лет обучения в России восприятия образа русского носителя русского языка в сознании туркменских инофонов. Этому, безусловно, способствуют отмеченные и предложенные нами виды работ. 


\section{Литература}

1- Абезгауз Е. С. (2011). Лингвострановедческая лексика в русском языке конияа $X X$ - начала XXI вв. / Дис. ... канд. филол. наук. - Краснодар.

2- Акишина А.А. (2017). Жесть и мимика в русской речи. Лингвострановедческий словарь. - М.: КРАСАНД.

3- Алефиренко Н.Ф. (2010). Лингвокультурология: ценностно-смысловое пространство языка: учеб. пос. - М.: Флинта: Наука.

4- Бадалова Е. Н. Бардина Е. Н., Голованева М. А., Желнова И. Л., Ивашкович Т. И., Нефёдова Д. С. (2020). Астрахань - каспийская столица. Лингвострановедение: Учебно-метод. пос. - Астрахань: ИД «Астраханский университет».

5- Багана Ж., Хапилина Е. В. (2010). Контактная лингвистика: Взаимодействие языков и билингвизм: монография. - М.: Флинта: Наука.

6- Баканова Ю. В. (2006). Воспитание основ межкультурной коммуникации у студентов в прочессе изучения иностранного языка // Сб. науч. тр. молодых ученых УралГУФК. - Вып. 5. - Челябинск: УралГУФК, 2006. 21-29.

7- Большой энциклопедический словарь (2006). - М.: АСТ.

8- Верещагин В. Г., Костомаров Е. М. (1980). Лингвострановедческая теория слова. - М.: Русский язык, 1980.

9- Верещагин Е. М., Костомаров В.Г. (1990). Язык и культура. Лингвострановедение в преподавании русского языка как иностранного. - М.: Наука.

10- Воробьева Е.И. (1999). Содержание $u$ структура понятия «лингвострановедческая компетенция учителя иностранного языка» // Аспекты лингвистических и методических исследований: Сб. науч. тр. Архангельск.

11- Гальскова Н. Д. (2004). Межкультурное обучение: проблема целей $и$ содержания обучения иностранным языкам // ИЯШ. - 2004. - № 1. - 22-27.

12- Грушевицкая Т.Г., Попков межкультурной коммуникации: Учеб. для вузов. - М.: ЮНИТА-ДАНА,

13- Ефремова Т. Ф. (2015). Самый полный толковый словарь русского языка в 3-х moмax. - T 3. - M.: ACT.

14- Карасик В.И. (2002). Культурные доминанты в языке // Карасик В.И. Языковой круг: личность, концепты, дискурс. - Волгоград: Перемена. 166205. 
15- Красножёнова Е.С. (2001). Роль лингвострановедческой компетенции преподавателя иностранного языка при обучении основам межкультурной коммуникации. - Москва: Флинта: Наука.

16- Лингвострановедение: научно-исследовательский практикум: Учеб.-метод. nос. (2017). - М., Берлин: Директ-Медиа.

17- Миролюбов А.А. (2002). История отечественной методики обучения иностранным языкам. - М.: СТУПЕНИ, ИНФРА-М.

18- Михайлов Н. Н. (2018). Лингвострановедение Англии / English Cultural Studies. - М.: Академия.

19- Ожегов С. И. (1989). Словарь русского языка. - М.: Русский язык.

20- Перевозникова А. К. (2018). Россия: Страна и люди: Учеб. пос. для изучающцих русский язык как иностранный. - М.: Русский язык. Курсы.

21- Попова 3. Д., Стернин И. А. (2002). Когнитивная лингвистика. - М.: Изд. «АСТ-Восток-Запад».

22- Прохоров Ю.Е. (1995). Лингвострановедение. Культуроведение. Страноведение. Теория и практика обучения русскому языку как иностранному: Метод. пособие для студентов-русистов и препод рус. языка иностранцам. - М.: Институт русского языка им. А. С. Пушкина.

23- Прохоров Ю. Е., Стернин И. А. (2011). Русские: коммуникативное поведение: учеб. пособие. - М.: Флинта: Наука.

24- Слышкин А.А. (2004). Лингвокультурные конщепты и метаконщепты. Волгоград: Перемена.

25- Тарасов Е.Ф. (1998) K построению теории межкультурного общения // Языковое сознание. Формирование и функиионирование. - М.: Ин-т языкознания РАН. - С. 30-42.

26- Тарасов Е.Ф. (1996). Межкультурное общение - новая онтология анализа языкового сознания // Этнокультурная специфика языкового сознания. - М.: Ин-т языкознания РАН. - С. 47-49.

27- Телия В.Н.(1999). Основные постулаты лингвокультурологии // Филология и культура: Материалы II междунар. конф. - Тамбов. - Ч. 3. - С. 14-15.

28- Тер-Минасова С. Г. (2007). Война и мир языков и культур: вопросы теории и практики: учеб. пос. - М.: АСТ: Астрель: Хранитель.

29- Тер-Минасова С. Г. (2000). Язык и межкультурная коммуникация: учеб. пос. М.: Слово/ Slovo.

30- Томахин Г. Д. (1996). Лингвострановедение: что это такое? // ИЯШ. - 1996. - № 6. - С. 47-49. 
31- Фелицкая В. П. (1990). Русские фразеологизмы. Лингвострановедческий словарь. - М.: Русский язык.

32- Щукин А.Н. (2003). Методика преподавания русского языка как иностранного: учеб. пособие. - М.: Высшая школа.

33- Carter R., Hughes R., McCarthy M. (2000). Exploring Grammar in Context. Cambridge University Press.

34- Ciggins P (2002). Ireland. Workbook, Longman.

35- Oschepkova V., McNicholas K. (2005). Guide to Country Studies. 1-2 Macmillan.

36- Scrivener J. (2005). Learning Teaching. A Guidebook for English Language teachers. 2-nd. ed. Macmillan Education.

37- Willis D. (2003). Rules, Patterns and Words. Grammar and Lexis in English Language Teachinag. Cambridge University Press.

\section{Bibliography}

1- Abezgauz E. S. (2011). Lingvostranovedcheskaja leksika v russkom jazyke konca $H H$ - nachala HHI vv. / Dis. ... kand. filol. nauk. - Krasnodar.

2- Akishina A. A. (2017). Zhesty i mimika v russkoj rechi. Lingvostranovedcheskij slovar'. - M.: KRASAND.

3- Alefirenko N. F. (2010). Lingvokul'turologija: cennostno-smyslovoe prostranstvo jazyka: ucheb. pos. - M.: Flinta: Nauka.

4- Badalova E. N. Bardina E. N., Golovaneva M. A., Zhelnova I. L., Ivashkovich T. I., Nefjodova D. S. (2020). Astrahan' - kaspijskaja stolica. Lingvostranovedenie: Uchebno-metod. pos. - Astrahan': ID «Astrahanskij universitet».

5- Bagana Zh., Hapilina E. V. (2010). Kontaktnaja lingvistika: Vzaimodejstvie jazykov i bilingvizm: monografija. - M.: Flinta: Nauka.

6- Bakanova Ju. V. (2006). Vospitanie osnov mezhkul'turnoj kommunikacii u studentov $v$ processe izuchenija inostrannogo jazyka // Sb. nauch. tr. molodyh uchenyh UralGUFK. - Vyp. 5. - Cheljabinsk: UralGUFK, 2006. 21-29.

7- Bol'shoj jenciklopedicheskij slovar' (2006). - M.: AST.

8- Vereshhagin V. G., Kostomarov E. M. (1980). Lingvostranovedcheskaja teorija slova. - M.: Russkij jazyk, 1980

9- Vereshhagin E. M., Kostomarov V. G. (1990). Jazyk i kul'tura. Lingvostranovedenie $v$ prepodavanii russkogo jazyka kak inostrannogo. - M.: Nauka. 
10- Vorob'eva E. I. (1999). Soderzhanie i struktura ponjatija «lingvostranovedcheskaja kompetencija uchitelja inostrannogo jazyka» // Aspekty lingvisticheskih $i$ metodicheskih issledovanij: Sb. nauch. tr. - Arhangel'sk.

11- Gal'skova N. D. (2004). Mezhkul'turnoe obuchenie: problema celej i soderzhanija obuchenija inostrannym jazykam // IJaSh. - 2004. - № 1. - 22-27.

12- 12.Grushevickaja T. G., Popkov V. D., Sadohin A. P. (2003) Osnovy mezhkul'turnoj kommunikacii: Ucheb. dlja vuzov. - M.: JuNITA-DANA,

13- Efremova T. F. (2015). Samyj polnyj tolkovyj slovar' russkogo jazyka v 3-h tomah. T 3. - M.: AST.

14- Karasik V. I. (2002). Kul'turnye dominanty v jazyke // Karasik V.I. Jazykovoj krug: lichnost', koncepty, diskurs. - Volgograd: Peremena. 166-205.

15- Krasnozhjonova E. S. (2001). Rol' lingvostranovedcheskoj kompetencii prepodavatelja inostrannogo jazyka pri obuchenii osnovam mezhkul'turnoj kommunikacii. - Moskva: Flinta: Nauka.

16- Lingvostranovedenie: nauchno-issledovatel'skij praktikum: Ucheb.-metod. pos. (2017). - M., Berlin: Direkt-Media.

17- Miroljubov A. A. (2002). Istorija otechestvennoj metodiki obuchenija inostrannym jazykam. - M.: STUPENI, INFRA-M.

18- Mihajlov N. N. (2018). Lingvostranovedenie Anglii / English Cultural Studies. M.: Akademija.

19- Ozhegov S. I. (1989). Slovar' russkogo jazyka. - M.: Russkij jazyk.

20- Perevoznikova A. K. (2018). Rossija: Strana i ljudi: Ucheb. pos. dlja izuchajushhih russkij jazyk kak inostrannyj. - M.: Russkij jazyk. Kursy.

21- Popova Z. D., Sternin I. A. (2002). Kognitivnaja lingvistika. - M.: Izd. «ASTVostok-Zapad».

22- Prohorov Ju. E. (1995). Lingvostranovedenie. Kul'turovedenie. Stranovedenie. Teorija i praktika obuchenija russkomu jazyku kak inostrannomu: Metod. posobie dlja studentov-rusistov i prepod rus. jazyka inostrancam. - M.: Institut russkogo jazyka im. A. S. Pushkina.

23- Prohorov Ju. E., Sternin I. A. (2011). Russkie: kommunikativnoe povedenie: ucheb. posobie. - M.: Flinta: Nauka.

24- Slyshkin A. A. (2004). Lingvokul'turnye koncepty i metakoncepty. - Volgograd: Peremena.

25- Tarasov E. F. (1998). K postroeniju teorii mezhkul'turnogo obshhenija // Jazykovoe soznanie. Formirovanie i funkcionirovanie. - M.: In-t jazykoznanija RAN. - S. 3042. 
26- Tarasov E. F. (1996). Mezhkul'turnoe obshhenie - novaja ontologija analiza jazykovogo soznanija // Jetnokul'turnaja specifika jazykovogo soznanija. - M.: In-t jazykoznanija RAN. - S. 47-49.

27- Telija V. N. (1999). Osnovnye postulaty lingvokul'turologii // Filologija i kul'tura: Materialy II mezhdunar. konf. - Tambov. - Ch. 3. - S. 14-15.

28- Ter-Minasova S. G. (2007). Vojna i mir jazykov i kul'tur: voprosy teorii i praktiki: ucheb. pos. - M.: AST: Astrel': Hranitel'.

29- Ter-Minasova S. G. (2000). Jazyk i mezhkul'turnaja kommunikacija: ucheb. pos. M.: Slovo/ Slovo.

30- Tomahin G. D. (1996). Lingvostranovedenie: chto jeto takoe? // IJaSh. - 1996. - № 6. - S. 47-49.

31- Felickaja V. P. (1990). Russkie frazeologizmy. Lingvostranovedcheskij slovar'. M.: Russkij jazyk.

32- Shhukin A. N. (2003). Metodika prepodavanija russkogo jazyka kak inostrannogo: ucheb. posobie. - M.: Vysshaja shkola.

33- Carter R., Hughes R., McCarthy M. (2000). Exploring Grammar in Context. Cambridge University Press.

34- Ciggins P. (2002). Ireland. Workbook Longman.

35- Oschepkova V., McNicholas K. (2005). Guide to Country Studies. 1-2 Macmillan.

36- Scrivener J. (2005). Learning Teaching. A Guidebook for English Language teachers. 2-nd. ed. Macmillan Education.

37- Willis D. (2003). Rules, Patterns and Words. Grammar and Lexis in English Language Teachinag. Cambridge University Press.

\section{HOW TO CITE THIS ARTICLE}

Golovaneva, M.A., Saparova O.A. \& Saparov A.A. (2021). Lingo-Cognitive Aspects as a Formation of an Image of a Native

Russian Speaker for a Foreigner While Studying In Russia. Issledovatel'skiy Zhurnal Russkogo Yazyka I Literatury, 9(2), 111-131.

DOI: $10.52547 /$ iarll.18.111

URL: https://journaliarll.ir/index.php/iarll/article/view/208

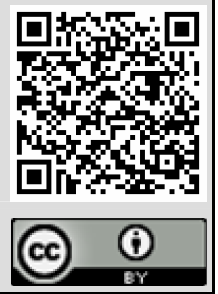




\section{جنبهاى زبانشناختى شكل گيرى تصوير شخص اهل زبان روسى در يك}

$$
\begin{aligned}
& \text { شخص خارجى در فرايند تحصيل در روسيه }
\end{aligned}
$$

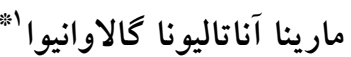

$$
\begin{aligned}
& \text { دانشيار، دانشخاه دولتى آَّتراخان، آستراخان، آلانيان روسيه. }
\end{aligned}
$$

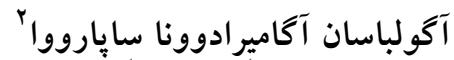

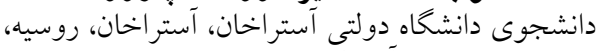

$$
\begin{aligned}
& \text { أستر اخخان، روسيه. }
\end{aligned}
$$

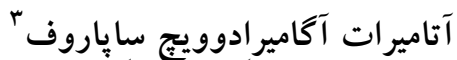



$$
\begin{aligned}
& \text { آستر اخلان، روسيه. }
\end{aligned}
$$

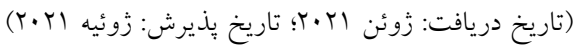



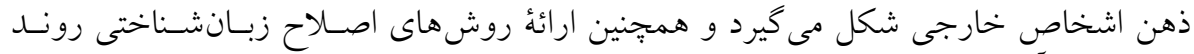

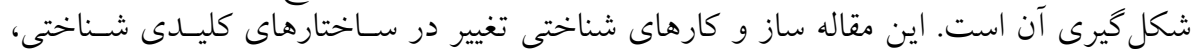

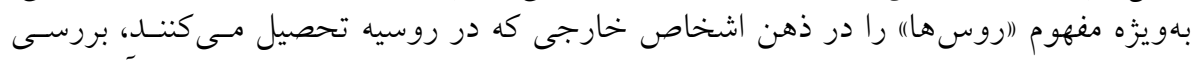

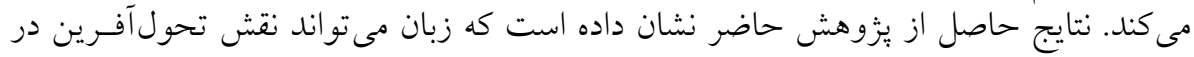

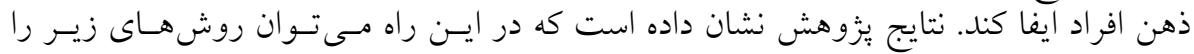

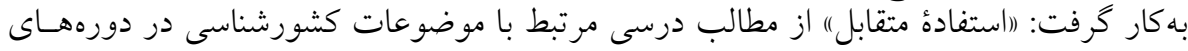

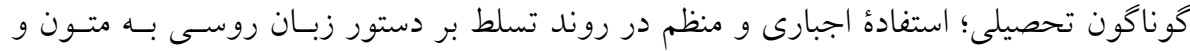

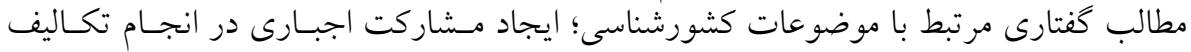

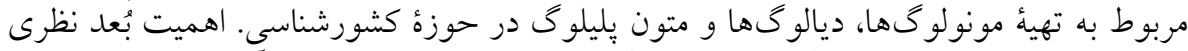



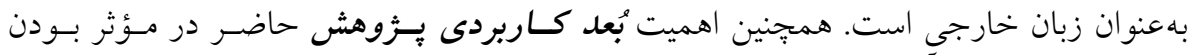

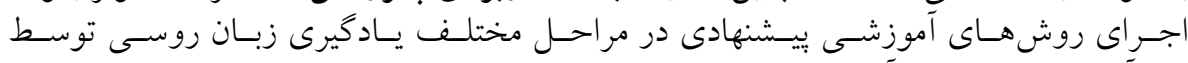

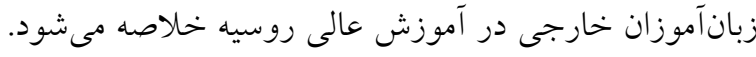

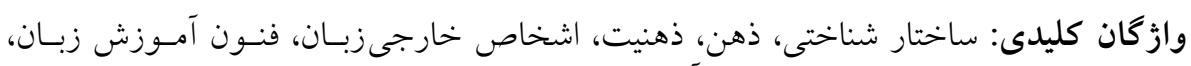

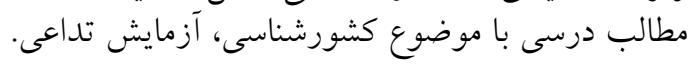

1. E-mail: yarrow@inbox.ru * نويسنده مسئول

2. E-mail: bossansaparova@mail.ru

3. E-mail: atamyratsaparov@mail.ru نوع مقاله: علمى - يُزوهشى 